\title{
Effects of Low Temperature on Somatic Embryos Growth, Maturation and Planlet Regeneration of Citrus Mandarin var Batu 55 (Citrus reticulata Blanco.)
}

\author{
Mufidatur Rosyidah ${ }^{1}$, Wahyu Widoretno ${ }^{2 *}$, Serafinah Indriyani ${ }^{2}$ \\ ${ }^{1}$ Master Program of Biology, Faculty of Mathematics and Natural Sciences, University of Brawijaya, Malang, Indonesia \\ ${ }^{2}$ Department of Biology, Faculty of Mathematics and Natural Sciences, University of Brawijaya, Malang, Indonesia
}

\begin{abstract}
This study was aimed to determine the effect of incubation at $4^{\circ} \mathrm{C}$ temperature during multiplication stage of somatic embryos on growth, maturation and plantlets regeneration of citrus Mandarin var Batu 55. Globular somatic embryos were cultured on MT (Murashige \& Tucker) medium and incubated at $4^{\circ} \mathrm{C}$ temperature for $0,2,4,6,8$ weeks. Maturation of somatic embryos was induced by transfering globular somatic embryos on maturation medium (MT + 50 $\mathrm{mgl}^{-1}$ malt extract $+73 \mathrm{mM}$ sorbitol $+73 \mathrm{mM}$ galactose). Cotyledonary embryo was regenerated on MT medium +50 $\mathrm{mgl}^{-1}$ malt extract $+30 \mathrm{gL}^{-1}$ sucrose $+2 \mathrm{ppm} \mathrm{GA}$. The research showed that maturation of somatic embyos at $4^{\circ} \mathrm{C}$ temperature inhibited growth and maturation of somatic embyos. Fresh weight of somatic embryo incubated at $4^{\circ} \mathrm{C}$ for 2 weeks lower than fresh weight of embryo cultured without incubation at $4^{\circ} \mathrm{C}$, and continuous decline in longer incubation period. Maturation percentage of embryos without incubation at $4^{\circ} \mathrm{C}$ temperature was $15 \%$, but embryos incubated at $4^{\circ} \mathrm{C}$ temperature were lower than $9 \%$. There was no effect of incubation at $4^{\circ} \mathrm{C}$ temperature during somatic embryos multiplication stage on plantlet regeneration percentage.
\end{abstract}

Keywords: Citrus reticulata, maturation, plantlet regeneration, somatic embryo

\section{INTRODUCTION}

Citrus Mandarin var Batu 55 is one of the most economically important citrus variety in Indonesia caused of sweet taste a bit sour, soft textured fruit, easy to peel and almost seedless. This superior characteristic caused high market demand. But this productivity could not been able to fulfill the national citrus demand. One of the efforts to increase productivity was through the provision of citrus seedling. Micropropagation through somatic embryogenesis is an effective method of plant propagation in large scale for mass seedling production such as citrus [1], apple [2], mango [3] and other fruit plant.

Regeneration of citrus Mandarin var Batu 55 through culture techniques have been successfully carried through somatic embryogenesis techniques using nucellar as an explant [4]. However plant regenerated from in vitro technique has long juvenile period ranging from 3-5 years [5]. Thus it was capable for producing citrus rootstock. Therefore it was necessary to find a method to produce citrus scion with short juvenile period.

\footnotetext{
* Correspondence author: Wahyu Widoretno

Email : wahyu_widoretno@yahoo.com

Address : Department of Biology, University of Brawijaya, Jl. Veteran Malang, 65145
}

Modification of culture conditions such as photoperiod and low temperature treatment has been able to reduce the juvenile period of plants seedling regenerated from in vitro culture.

Low temperature exposure successfully stimulated flowering in some plants such as in Cinchorium intybus [6] and Oenothera fructicosa [7]. Low temperature treatment given during somatic embryos multiplication stage could produce plant with short juvenile period, but it was also affected the growth and development of somatic embryos. This study aimed to evaluate the effect of low temperatures treatment on somatic embryos growth, maturation and plantlets regeneration of citrus Mandarin var Batu 55.

\section{MATERIALS AND METHODS}

Induction and multiplication of somatic embryos

Somatic embryos were obtained from nucellus explant cultured on $\mathrm{MT}$ medium $+50 \mathrm{gL}^{-1}$ sucrose $+3 \mathrm{ppm} \mathrm{BAP}+50 \mathrm{mgL}^{-1}$ malt extract, cultured incubated at room temperature as long as two months [8]. Embryogenic calli subcultured on MT medium $+30 \mathrm{gL}^{-1}$ sucrose every 6 weeks, and cultured at $25^{\circ} \mathrm{C} \pm 2^{\circ} \mathrm{C}$. Somatic embryos that have undergone three times subculture used as explants for low temperature treatment. 


\section{Low temperature treatment}

Globular stage somatic embryos were incubated at $4^{\circ} \mathrm{C}$ for $2,4,6,8$ weeks, whereas the controll was embryos incubated in temperature room. Each treatment was repeated 5 times (5 bottles), each bottle was cultured with one clump embryos $(0.1 \mathrm{~g})$. After each incubation period, embryos were incubation in room temperature as long as two month. Somatic embryos growth was examined by measuring somatic embryo fresh weight.

Somatic embryo maturation and plantlet regeneration

Embryo without incubation at $4^{\circ} \mathrm{C}$ and embryos in temperature $4^{\circ} \mathrm{C}$ treatment were transfered to $\mathrm{MT}+50 \mathrm{mgl}^{-1}$ malt extract $+73 \mathrm{mM}$ sorbitol $+73 \mathrm{mM}$ galactose. Culture incubated in room temperature for three months, then number of cotyledonary embryo and maturation percentage was counted.

Cotyledonary somatyc embryos were germina-ted on MT medium $+30 \mathrm{gL}^{-1}$ sucrose + $50 \mathrm{mgL}^{-1}$ malt extract $+2 \mathrm{ppm} \mathrm{GA}$. Each bottle was culture with 10 embryos and incubated at room temperature for three months, then number of plantlet and plantlet regeneration percentage were counted.

\section{Data Analysis}

The data of somatic embryo growth, percentage of maturation and percentage of planlet regeneration were analyzed by the ANOVA test $(p<0.05)$. Significant difference was test by Duncan's multiple range test $(p<0.05)$.

\section{RESULT AND DISCUSSION}

Effect of low temperature treatment on somatic embryo growth

Low temperature did not affect the morphology of embryos, but affected somatic embryos growth reflected by different size of embryo clump in each incubation period. Increasing incubation period at $4^{\circ} \mathrm{C}$ increasingly inhibit the growth of somatic embryos, it is shown in smaller clump size. Incubation at $4^{\circ} \mathrm{C}$ temperature during embryo multiplication stage decreased somatic embryos fresh weight. Fresh weight of somatic embryo incubated $4^{\circ} \mathrm{C}$ for 2 weeks was lower than embryos incubated at room temperature and continuous decline in longer incubation period. Fresh weight of untreated embryo reaches $0.61 \mathrm{~g}$, treated embryo are low than $0.5 \mathrm{~g}$. The lowest fresh weight was showed by somatic embryo cultured in $4{ }^{\circ} \mathrm{C}$ treatment for 8 weeks in the amount of $0,17 \mathrm{~g}$ (Fig. 1).

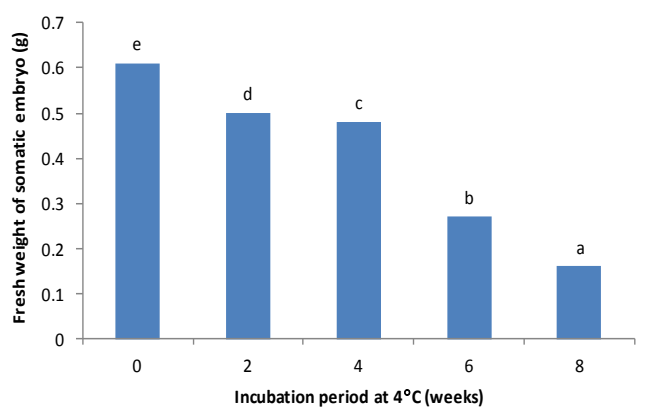

Figure 1. The effect of low temperature treatment on fresh weight of somatic embryo

The same letter for each incubation period showed no significantly difference between means by Duncan test $5 \%$.

Effect of low temperature treatment on somatic embryo maturation and plantlet regeneration

After transfered on maturation medium as long as two months embryos was mature, showed by changing in color of embyos, which initially appearss milky white to yellow with green spots. After three months cultured on maturation medium, there were found globular phase, heart-shaped, torpedo and cotyledonary embryo (Fig. $2 \mathrm{~A}-\mathrm{E}$ ). Incubation at $4^{\circ} \mathrm{C}$ during multiplication stage inhibited somatic embryos growth and maturation. Somatic embryos incubated at $4^{\circ} \mathrm{C}$ produces fewer cotyledonary embryos than embryo incubated at room temperature (Fig. 2F-J). Somatic embryos incubated at room temperature and embryos incubated at $4^{\circ} \mathrm{C}$ able to regenerate into plantlets (Figure $3 \mathrm{~A}-\mathrm{B}$ ). Plantlets which regenerated from embryos incubated at $4^{\circ} \mathrm{C}$ more than 4 weeks showed stunted growth (Figure $3 \mathrm{C}$ ).

Incubation of somatic embryos at $4^{\circ} \mathrm{C}$ decreased maturation percentage. Somatic embryos incubated at $4^{\circ} \mathrm{C}$ show a higher percentage of maturation and number of cotyledonary embryos. The number of cotyledonary embryo and maturation percentage decreased with increasing incubation period at $4^{\circ} \mathrm{C}$ treatment. Maturation percentage of embryos incubated at room temperature was reach $15 \%$ with number of cotyledonary embryos was 25 embryos, whereas embryos incubated at $4^{\circ} \mathrm{C}$ for 4 weeks was $9 \%$ with number of cotyledonary embryo was 15 Maturation percentage and number of cotyledonary embryo in longer incubation period wass less than $6 \%$ with number of cotyledonary embryo was about 5-11 embryos (Fig. 4A). 

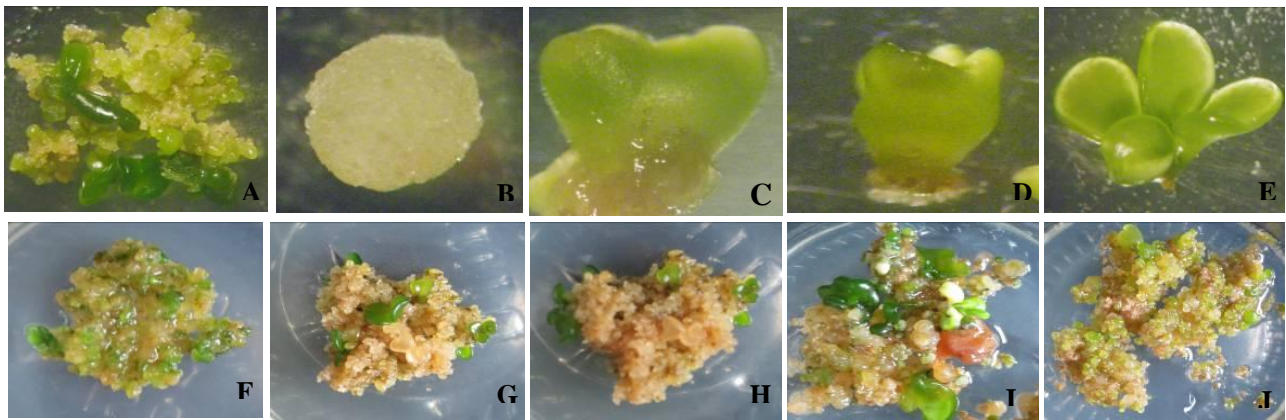

Figure 2. Developmental stage of Citrus Mandarin var Batu 55 somatic embryos after incubated at $4{ }^{\circ} \mathrm{C}$ temperature. A. Embryo started mature; B. Globular phase; C. Heart-shaped; D. Torpedo; E. Cotiledonary; F. Eembryoss incubated at room temperature; G. Embryos incubated at $4{ }^{\circ} \mathrm{C}$ for 2 weeks; H. 4 weeks; I. 6 weeks; J. 8 weeks
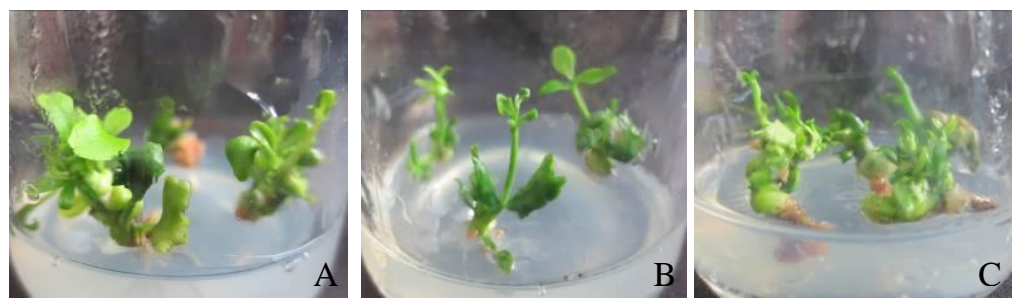

Figure 3. Plantlets regeneration from somatic embryos of Citrus Mandarin var Batu 55.

A. Planlet regenerated from embryos incubated at room temperature; B-C. Plantlet regenerated from embryos incubated at $4^{\circ} \mathrm{C}$ for 2 and 8 weeks.
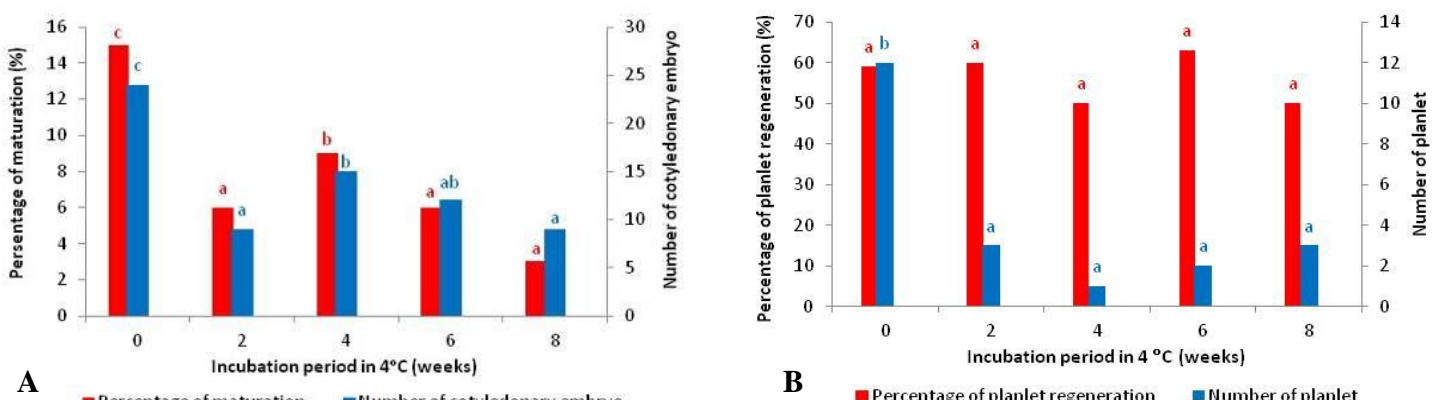

- Percentage of maturation Number of cotyledonary embryo

B

- Percentage of planlet regeneration $\quad$ Number of planlet

Figure 4.The percentage of somatic embryo maturation and the percentage of planlet regeneration of Citrus Keprok Batu 55 A. Percentage of maturation; B. Percentage of plantlet regeneration. The same letter for each maturation and plantlet regeneration percentage showed no significantly difference between means by Duncan test $5 \%$.

There was no significant difference in planlet regeneration percentage between embryos incubated at room temperature and embryos at $4^{\circ} \mathrm{C}$. Planlet regeneration percentage of embryos incu-bated at room temperature and embryos incubated at $4^{\circ} \mathrm{C}$ was less than $60 \%$.

Although there was no significant difference of plantlet regeneration percentage, but there was a significant difference between numbers of plantlet. Incubation of somatic embryos at $4^{\circ} \mathrm{C}$ temperature decreased the number of plantlet, number of plantlet regenerated from embryos incubated at room temperature was reach 12 , whereas number of planlet regenerated from embryos incubated at $4^{\circ} \mathrm{C}$ less than 3 (Fig. 4B).

Incubation at $4^{\circ} \mathrm{C}$ temperature during somatic embryo multiplication step inhibited growth and development of somatic embryos. This may occur because $4^{\circ} \mathrm{C}$ temperature cause physiological stress that interfere with cell metabolism such as photosynthesis, respiration, water content, and the stability of the membrane, cell ultrastructure damage. Furthermore it led to decreased cell divission and differentiation and embryogenesis [9]. Low temperature treatment causes changes in wall and cell membrane interactions, which cause any changes in gene expression and proteins synthesis that play a role in the development of somatic embryos. In addition, these proteins may be a key protein that induces maturation and germination of somatic embryos resulted an abnormal embryos [10]. Abnormal embryos morphology tends to be slow to form plantlets because it can lead to blocking the 
development of the embryo in the early stages of somatic embryo development. Plantlets formed from abnormal embryos showed gigantic growth followed by none formation of buds, but capable of forming roots [11].

Eventhough low temperature caused abnormalities of somatic embryos, low temperature was also essential for maturing somatic embryo and germination in Vitis vinifera $x$ Vitis ruprestis. Globular stage embryo culture of grape (Vitis vinifera) was treated with $4^{\circ} \mathrm{C}$ temperature for two weeks, showed increasing in somatic embryo maturation percentage [12].

\section{CONCLUSION}

Incubation at $4^{\circ} \mathrm{C}$ temperature affected growth and development of somatic embryo in Citrus Mandarin var Batu 55. Incubation at $4^{\circ} \mathrm{C}$ decreased somatic embryo fresh weight and percentage of maturation. Somatic embryo incubated at room temperature and embryos incubated at $4^{\circ} \mathrm{C}$ able to regenerated into planlet. Althought there was no affect on plantlets regeneration percentage, but number of planlet regenerated from embryo incubated at $4^{\circ} \mathrm{C}$ was lower. The lowest fresh weigh, maturation and plantlets regeneration percentage showed by embryos incubated at $4^{\circ} \mathrm{C}$ temperature treatment for 8 weeks, in addition regenerated plantlets showed stunted growth.

\section{REFERENCES}

[1] Husni, A., A. Purwito, I. Mariska, Sudarsono. 2010. Regenerasi Jeruk Siam melalui embriogenesis somatik. Jurnal Agrobiogen. 6. 75-83.

[2] Paul, H., M. Belaizi, B.S.S. Norrel. 1994. Somatic embryogenesis in apple. J. Plant Physiol. 143. 78-86.

[3] Nower, A.A. 2013. In Vitro production of somatic embryos from nucellus of Mango (Mangifera Indica L). Life Sci. J. 10. 22-26.

[4] Merigo, J.A. 2011. Studi regenerasi tanaman Jeruk Keprok Batu 55 (Citrus reticulata L.) melalui jalur embriogenesis somatik. Master Thesis. Bogor Agricultural University. Bogor.

[5] Aubert, B., V. Guy. 1997. Citrus nurseries and planting technique. CIRAD Publishing. Paris.

[6] Ziv, M., N. Vered. 2006. Flowering of geophytes In Vitro. Propag. Ornam. Plant. 6. 3-16.

[7] Clough, E.A., C.C. Arthur, D.H. Royal, H.C. William. 2001. Growth and development of Oenothera fructicosa is influenced by vernalization duration, photoperiod, forcing temperature, and plant growth regulator. J. Amer. Soc. Hort. Scr. 126. 269-274.

[8] Widoretno, W., C. Martasari, F.F. Nirmala. 2013. Pengaruh sukrosa dan fotoperiode terhadap embriogenesis Jeruk Keprok Batu 55 (Citrus reticulata Blanco). J. Hort. Indonesia. 4. 44-53.

[9] Cutanda, M.C., A.B. Ouquet, P. Chatelet, G. Lopez, C. Botella, F.J. Montero, L. Torregrosa. 2008. Somatic embryogenesis and Plant Regeneration of Vitis vinifera Cultivars 'Macabeo' and 'Tempranillo'. Vitis. 47. 156-162.

[10] Corredoira, E., A.M. Ballester, A.M. Viertiez. 2003. Proliferation, maturation, and germination of Castanea sativa Mill. somatic embryo originated from leaf explants. Ann. Bot.-London. 92. 129-136.

[11] Lukatkin, A.S., A. Brazaityte, C. Bobinas, P. Duchovskis. 2012. Chilling injury in chillingsensitive plants: a review. Zemdirbyste Agr. 99. 111-124.

[12] Angelakis, K.A.R. 2009. Grapevine molecular phisiology and biotechnology. Spinger Dordrecht Heidelberg. London. 